\title{
Synthesis Characterization and Biological Application of 2,3,4-Trimethoxy Benzaldehyde Semicarbazone Co(II) Metal Ions
}

\section{Vidhya RS ${ }^{1}$ and Rathika Nath $\mathbf{G}^{2}$}

${ }^{1}$ ST Hindu College, Nagercoil, Tamil Nadu, India

${ }^{2} D B$ College, Sasthamcotta, Kollam, Kerala, India

\begin{abstract}
$\left[\mathrm{Co}\left(\mathrm{L}_{4}\right)_{2} \mathrm{Cl}_{2}\right]$ were prepared by reacting 2,3,4-trimethoxy benzaldehyde semi carbazone ligands with $\mathrm{CoCl}_{2} \cdot 6 \mathrm{H}_{2} \mathrm{O}$. The IR, UV, Mass and ${ }^{1} \mathrm{H}$ NMR spectra of the complexes have been assigned. Thermo gravimetric analysis were also carried out. The data agree quite well with the proposed structures and show that the complexes were finally decomposed to the corresponding ligands. Complexes were screened for antimicrobial activities by the disc diffusion technique using DMSO as solvent. The activity data show that the semi carbazone metal complexes are more potent antimicrobials metal complexes.
\end{abstract}

Keywords: 2,3,4-Trimethoxy benzaldehyde; Semi carbazone; Metal complexes; IR; ${ }^{1} \mathrm{H}$ NMR; Antimicrobial activity

\section{Introduction}

Stereochemistry of coordination compounds plays a major role in their activities. The existence of electronegative nitrogen, oxygen or sulfur atoms on the ligand structure is seen to improve the coordination potential of ligands. The expansion of instrumental techniques provides way of investigating thermal, spectral and magnetic properties of metal complexes. Metal complex preparation from Schiff base ligands [1] which is a large area studied both in solution as well as in the solid state, have attained significant consequence due to their obvious biological activity. The effects of azomethine ylide with alkenes have been investigated from a speculative point of view in order to recognize the reaction path, selectivity on the effect [2]. Typically, semicarbazone derivatives are prepared through the reaction of aldehydes or ketones [3] with semicarbazide in presence of an acid or a base, as catalyst. A variety of semicarbazone [4] derivatives could be prepared in quantitative yields, by mixing stoichiometric amounts of suitable aldehydes with respective semicarbazides. Ketones usually need elevated temperatures than aldehydes for whole conversion. Schiff base ligands for the preparation of metal complexes of semi carbazones have been receiving considerable attention, largely because of their peculiar properties. Schiff bases play a vital role in inorganic chemistry as they easily form stable complexes with most transition metal ions in the periodic table [5-7].

\section{Materials and Methods}

All chemicals used were of analytical reagent grade (AR) and procured from Sigma-Aldrich and Flock and the metal salts were purchased from E. Merck and used as received.

\section{Synthesis of ligand}

0.01 mole of the corresponding aldehyde in ethanol (2,3,4-trimethoxy benzaldehyde) in cold ethanol was added to a 250 $\mathrm{ml}$ RB flask containing 0.01 mole of semicarbazide in hot water. The mixture was refluxed for about 4 to 5 hours at $80^{\circ} \mathrm{C}$, with continuous stirring, and then allowed to cool overnight at room temperature. The isolated yellow colored precipitate was filtered, washed with cold ethanol and dried under vacuum (Figure 1).

\section{Synthesis of metal complexes}

Aqueous solution of the corresponding metal salt (0.01 mole),
(Cobalt Chloride hexahydrate) was individually mixed with hot ethanolic solution of the corresponding ligand $(0.02$ mole). The mixture was refluxed for $4-5$ hours at $70-80^{\circ} \mathrm{C}$ with continuous stirring, allowed to cool overnight at room temperature to yield brown colored metal complexes. The products were filtered, washed with $50 \%$ ethanol, and dried under vacuum (Figure 2).

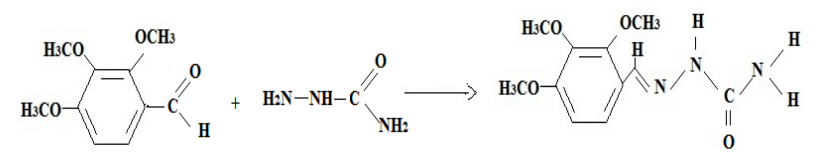

Figure 1: Preparation of $\mathrm{Co}\left(\mathrm{L}_{4}\right)_{2} \mathrm{Cl}_{2}$

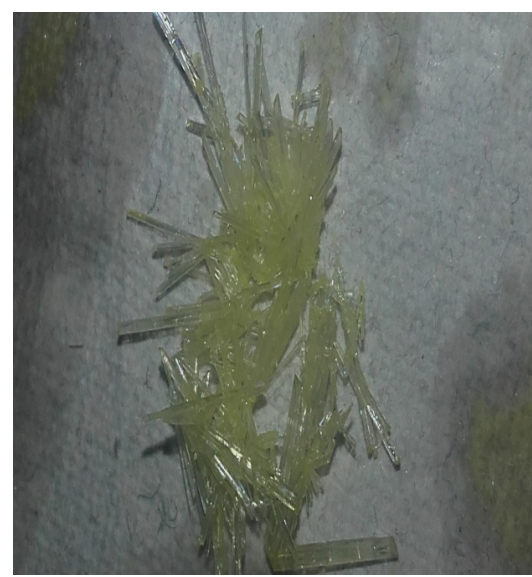

Figure 2: Crystal formation of $\left[\mathrm{Co}\left(\mathrm{L}_{4}\right)_{2}\right]$ complex.

*Corresponding author: Vidhya RS, Faculty at ST Hindu College, Nagercoil Tamil Nadu, India, Tel: +914652225940; E-mail: vidhya276@gmail.com

Received November 13, 2017; Accepted November 20, 2017; Published November 23, 2017

Citation: Vidhya RS, Rathika Nath G (2017) Synthesis Characterization and Biological Application of 2,3,4-Trimethoxy Benzaldehyde Semicarbazone Co(II) Metal lons. Chem Sci J 8: 176. doi: 10.4172/2150-3494.1000176

Copyright: (c) 2017 Vidhya RS, et al. This is an open-access article distributed under the terms of the Creative Commons Attribution License, which permits unrestricted use, distribution, and reproduction in any medium, provided the original author and source are credited. 


\section{Physical parameters of ligand and their metal complexes}

Schiff bases were prepared in 1:1 ratio and the Schiff base metal complexes prepared by 1:2 ratio. All the metal complexes were found to be soluble in DMSO. Physical parameters of the resulting complexes are summarized below Table 1.

\section{Elemental analysis}

Elemental analysis of ligand $\mathrm{L}_{4}\left(\mathrm{C}_{11} \mathrm{H}_{15} \mathrm{~N}_{3} \mathrm{O}_{4}\right)$ found (calc.) (\%), C, 52.14 (52.16); H, 5.95 (5.98); N, 16.60 (16.59); O, 25.31 (25.27). Metal complexes like $\left[\mathrm{Co}\left(\mathrm{C}_{11} \mathrm{H}_{15} \mathrm{~N}_{3} \mathrm{O}_{4}\right)\right.$ ] $]$ :, $46.76(46.72) ; \mathrm{H}, 5.33(5.36) ; \mathrm{N}$, 14.85 (14.86); O, 22.62 (22.63); M, 10.43 (10.42) (Table 2).

\section{Spectral and thermal characterization data}

IR spectral analysis $L_{4}$ and its metal complexes: The IR spectra of $\mathrm{L}_{4}$ and its metal complexes are provided below (Figures 3 and 4 ). IR absorption band in the region $1707.00 \mathrm{~cm}^{-1}$ can be attributed to the $\mathrm{C}=\mathrm{O}$ stretching vibration of $\mathrm{L}_{4}$, while its transition metal show absorption shifted to values $1706.93 \mathrm{~cm}^{-1}$, in $\mathrm{CoCl}_{2}$ respectively. $1593.20 \mathrm{~cm}^{-1}$ in the spectrum assigned to the azomethine $(\mathrm{C}=\mathrm{N})$ vibration. This is seen to suffer lower shift to values around $1591.27 \mathrm{~cm}^{-1}$ in the complexes of $\mathrm{CoCl}_{2}$ (Table 3). In the case of metal complexes, the appearance of bands (M-N) in the region of $520.78 \mathrm{~cm}^{-1}$ in $\mathrm{CoCl}_{2}$ and (M-O) show an absorption band at $420.48 \mathrm{~cm}^{-1}$ in $\mathrm{CoCl}_{2}$.

\section{UV spectral analysis}

The bands in the range $200-700 \mathrm{~nm}$ can be assigned to $\pi-\pi^{*}$ and/ or $\mathrm{n}-\pi^{\star}$ transitions. Absorption bands at around $250 \mathrm{~nm}$ was assigned to $3 \mathrm{~T} 1 \mathrm{~g}(\mathrm{P}) \leftarrow 3 \mathrm{~A} 2 \mathrm{~g}(\mathrm{~F})$ transition, in the electronic spectra of the 2,3,4-trimethoxy benzaldehyde semicarbazone $\mathrm{Co}(\mathrm{II})$ complex in DMSO (Figure 5).

\section{NMR spectral analysis}

${ }^{1} \mathrm{H}$ NMR Spectra of $\mathrm{L}_{4}$ : The $1 \mathrm{H}$ NMR spectrum of $\mathrm{L}_{4}$ in DMSO is shown in Figure 5 and peak assignments are given in the Table 4. Chemical Shifts of methoxy protons were observed as a single peak at $\delta 3.923(\mathrm{ppm})$. Chemical shift of aromatic proton was observed as a multiple at $\delta 7.375 \mathrm{ppm}$ (Figure 6). The azomethine proton appeared at $\delta 6.526(\mathrm{ppm})$. The signals of the $\mathrm{N}-\mathrm{NH}$ proton were observed as singlet at $\delta 8.401(\mathrm{ppm})$ and $-\mathrm{NH}_{2}$ proton signals observed as singlet at $\delta 7.617$ (ppm) (Table 4).

${ }^{13} \mathrm{C}$ NMR Spectra of $\mathrm{L}_{4}$ : The ${ }^{13} \mathrm{C}$ NMR spectrum of 2,3,4-trimethoxy benzaldehyde semicarbazone compounds $\left(\mathrm{L}_{4}\right)$ in DMSO is shown in Figure 6 and peak assignment are given in Table 5. The spectrum showed a signal at $82.850-83.824 \mathrm{ppm}$ which was assigned to methoxy carbon. The presence of carbonyl (ketone group) was found at around

\begin{tabular}{|c|c|c|c|c|c|}
\hline S. No. & Compound & $\begin{array}{c}\text { Molecular } \\
\text { weight }\end{array}$ & $\begin{array}{c}\text { Melting } \\
\text { point (C) }\end{array}$ & Color & $\begin{array}{c}\text { Molecular } \\
\text { Formula }\end{array}$ \\
\hline 1 & $\mathrm{~L}_{4}$ & 253.29 & 230 & Yellow & $\mathrm{C}_{11} \mathrm{H}_{15} \mathrm{~N}_{3} \mathrm{O}_{4}$ \\
\hline 2 & {$\left[\mathrm{Co}\left(\mathrm{L}_{4}\right)_{2}\right]$} & 565.51 & 210 & Brown & {$\left[\mathrm{Co}\left(\mathrm{C}_{11} \mathrm{H}_{15} \mathrm{~N}_{3} \mathrm{O}_{4}\right)_{2}\right]$} \\
\hline
\end{tabular}

Table 1: Physical parameters of the ligand and its $\mathrm{Co}$ (II) complex.

\begin{tabular}{|c|c|c|c|c|c|}
\hline \multirow{2}{*}{ Compound } & \multicolumn{5}{|c|}{ \%Observed (Calculated) } \\
\cline { 2 - 6 } & $\mathbf{C}$ & $\mathbf{H}$ & $\mathbf{N}$ & $\mathbf{O}$ & $\mathbf{M}$ \\
\hline \multirow{2}{*}{$\mathrm{C}_{11} \mathrm{H}_{15} \mathrm{~N}_{3} \mathrm{O}_{4}$} & 52.14 & 5.95 & 16.6 & 25.31 & - \\
\cline { 2 - 6 } & $(52.16)$ & $(5.98)$ & $(16.59)$ & $(25.27)$ & \\
\hline \multirow{2}{*}[\mathrm{Co}(\mathrm{C}_{11}\mathrm{H}_{15}\mathrm{N}_{3}\mathrm{O}_{4})_{2}]{} & 46.76 & 5.33 & 14.85 & 22.62 & 10.43 \\
\cline { 2 - 6 } & $(46.72)$ & $(5.36)$ & $(14.86)$ & $(22.63)$ & $(10.42)$ \\
\hline
\end{tabular}

Table 2: CHNS data table of $L_{4}$ and its complexes.

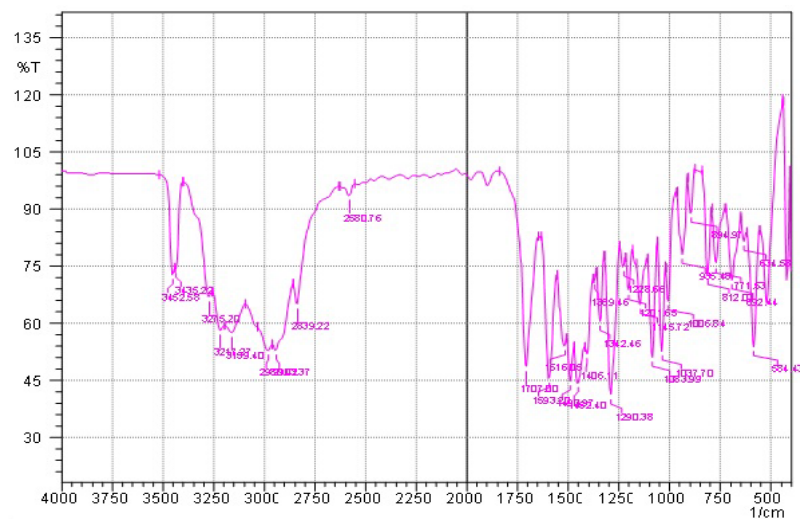

Figure 3: IR spectra of $L_{4}$

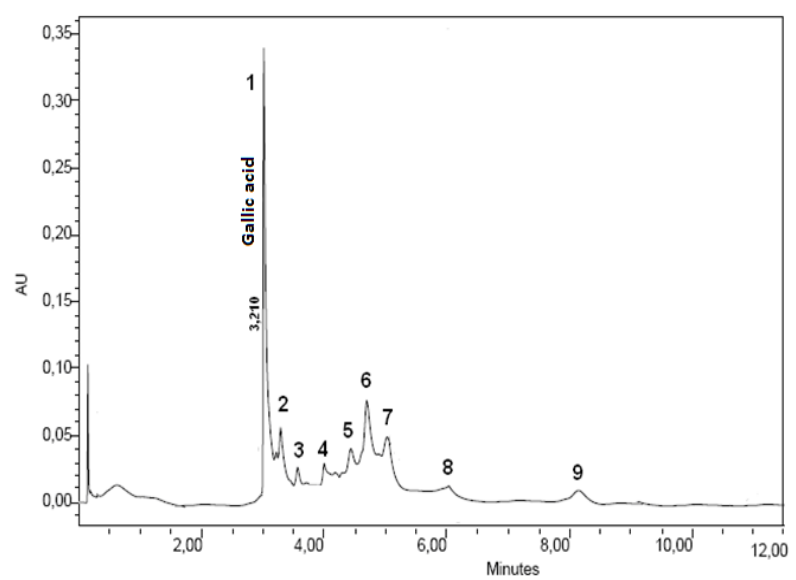

Figure 4: IR spectra of $\left[\mathrm{Co}\left(\mathrm{L}_{4}\right)_{2}\right]$.

\begin{tabular}{|c|c|c|c|c|c|}
\hline Compounds & $\mathbf{v}(\mathbf{C}=\mathbf{N})$ & $\mathbf{v}(\mathbf{N}-\mathbf{H})$ & $\mathbf{v}(\mathbf{C}=\mathbf{O})$ & $\mathbf{v}(\mathbf{M}-\mathbf{O})$ & $\mathbf{v}(\mathbf{M}-\mathbf{N})$ \\
\hline $\mathrm{L}_{4}$ & 1593.2 & 3275.2 & 1707 & - & - \\
\hline$\left[\mathrm{Co}\left(\mathrm{L}_{4}\right)_{2}\right]$ & 1591.27 & 3275.2 & 1706.93 & 420.48 & 520.78 \\
\hline
\end{tabular}

Table 3: IR spectral values of $L_{4}$ and its metal complexes.

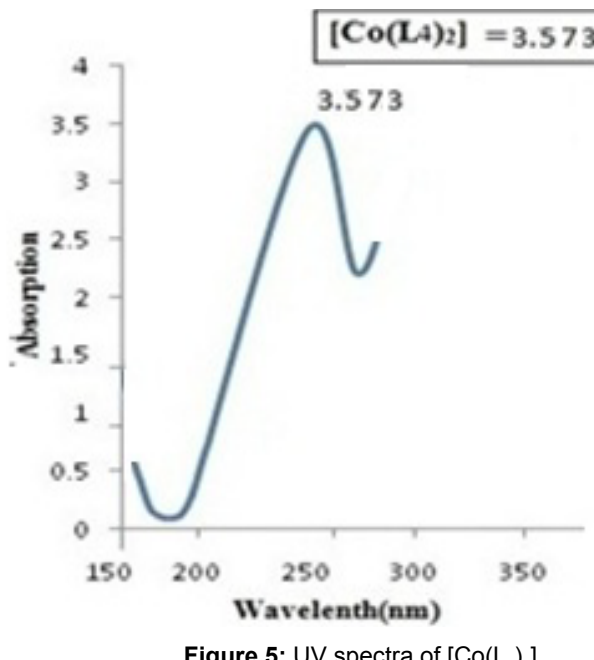

Figure 5: UV spectra of $\left[\mathrm{Co}\left(\mathrm{L}_{4}\right)_{2}\right]$. 


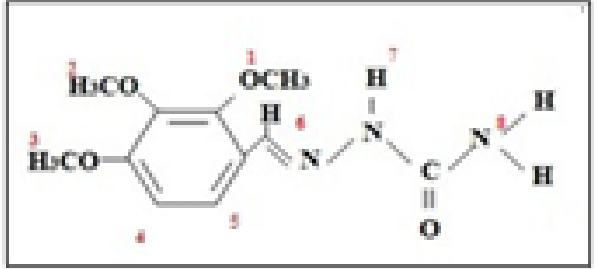

\begin{tabular}{|c|c|c|}
\hline Chemical Shift (ppm) & Mark & Assignments in DMSO \\
\hline $3.923,9 \mathrm{~h}, \mathrm{t}$ & $1,2,3$ & $\mathrm{OCH}_{3}$ Protons \\
\hline $7.375,2 \mathrm{~h}, \mathrm{~d}$ & 4,5 & Aromatic proton \\
\hline $6.526,1 \mathrm{H}, \mathrm{s}$ & 6 & Azomethine proton $(\mathrm{CH}=\mathrm{N})$ \\
\hline $8.401,1 \mathrm{H}, \mathrm{s} ; 7.617,1 \mathrm{H}, \mathrm{s}$ & 7,8 & Proton of $\mathrm{NH} \& \mathrm{NH}_{2}$ \\
\hline
\end{tabular}

Table 4: $H$ NMR spectra table of $L_{4}$.
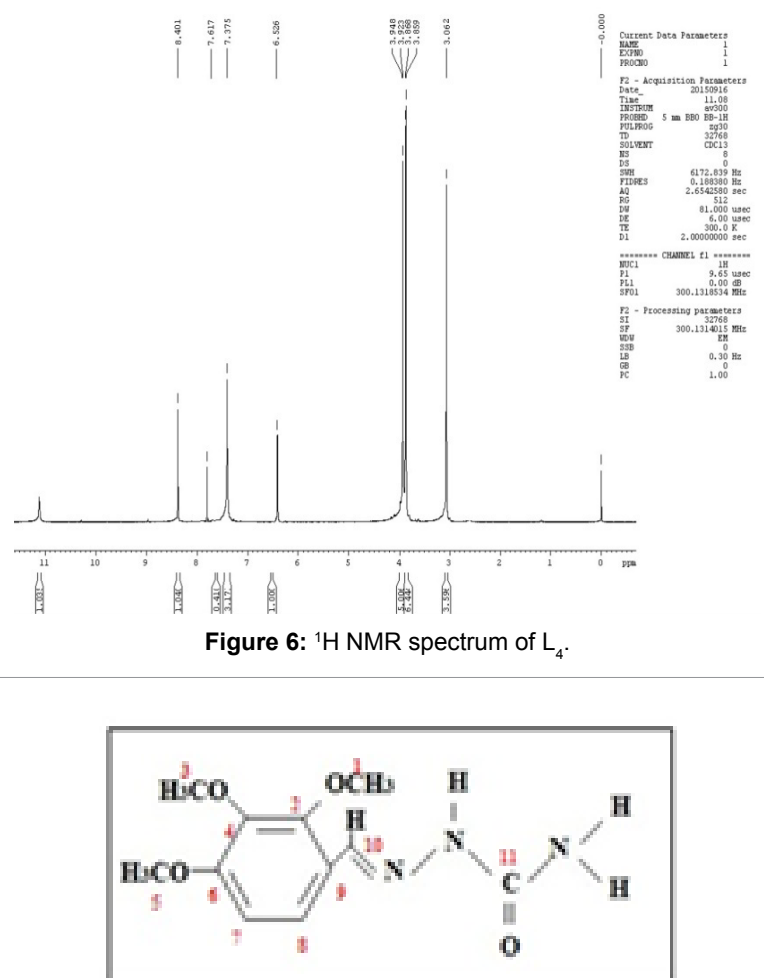

\begin{tabular}{|c|c|c|}
\hline Chemical Shift (ppm) & Mark & Assignments in DMSO \\
\hline $82.850-83.824$ & $2,4,6$ & Methoxy carbon \\
\hline $103.004-117.806$ & 7,8 & Aromatic Carbon \\
\hline $45.050-43.483$ & $1,3,5$ & Methylene Carbon (Benzyl Group) \\
\hline 162.53 & 10 & Azomethine Carbon $(\mathrm{CH}=\mathrm{N})$ \\
\hline 206.194 & 11 & Carbonyl (ketone) $(\mathrm{C}=\mathrm{O})$ \\
\hline \multicolumn{3}{|c}{ Table 5: C NMR spectra table of $\mathrm{L}$} \\
\hline
\end{tabular}

$206.194 \mathrm{ppm}$ and aromatic carbons within the range 103.004-117.806 ppm (Figure 7). The azomethine carbon atom exhibited a peak at $162.530 \mathrm{ppm}$. The peak observed at $45.050-43.483 \mathrm{ppm}$ may be due to methylene carbon (benzyl group) (Table 5).

\section{Mass spectral analysis}

The Electron impact mass spectrum of the ligand $\left(\mathrm{L}_{4}\right)$, Figure 7 shows a molecular ion $\left(\mathrm{M}^{+}\right)$peak at $\mathrm{m} / \mathrm{z}=253.29$ amu corresponding to species $\mathrm{C}_{11} \mathrm{H}_{15} \mathrm{~N}_{3} \mathrm{O}_{4}$ (Figure 8).

The intensities of the peaks give the idea of the strength of the fragments (Figure 9). The mass spectrum of the Co (II) complex showed a molecular ion peak at $\mathrm{m} / \mathrm{z}=565.51$ which was found to coincide with that of the molecular weight of the complex (Table 6).

\section{TG analysis}

Thermogram of the solid ligand shows that there is no weight loss up to $310^{\circ} \mathrm{C}$ (Figures 9 and 10). The horizontal portion of the curve indicate there is no change in weight $\left(0-200^{\circ} \mathrm{C}\right.$ and $\left.310-360^{\circ} \mathrm{C}\right)$ and the vertical potion indicate that there is weight change $\left(200-310^{\circ} \mathrm{C}\right)$.

Thermogram of the solid complexes shows that there is no weight loss up to $340^{\circ} \mathrm{C}$ signifying the lack of lattice as well as coordinated water molecule in complexes (Figures 10 and 11).

Thermogram indicates incomplete decay of ligand moiety. The

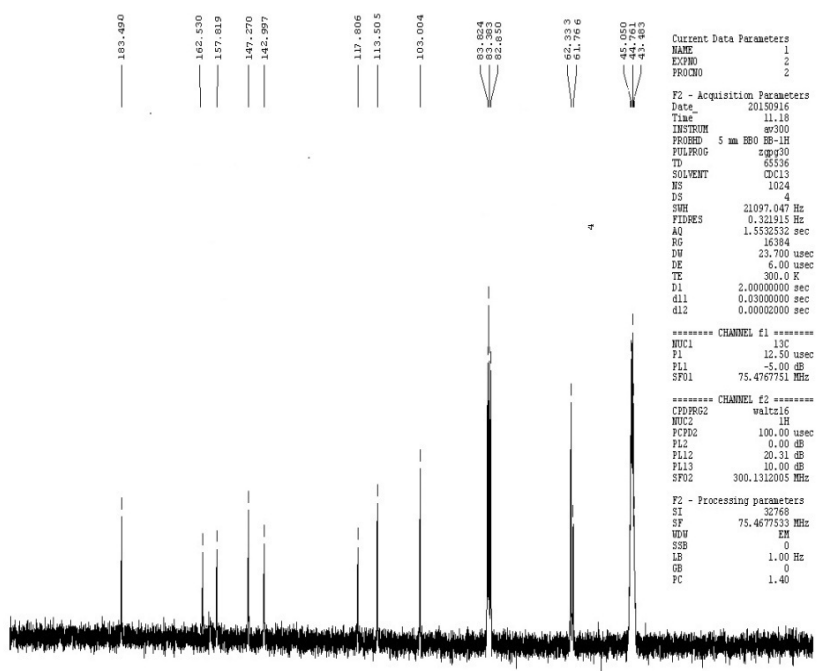

Figure 7: ${ }^{13} \mathrm{C}$ NMR spectra of $L_{4}$.

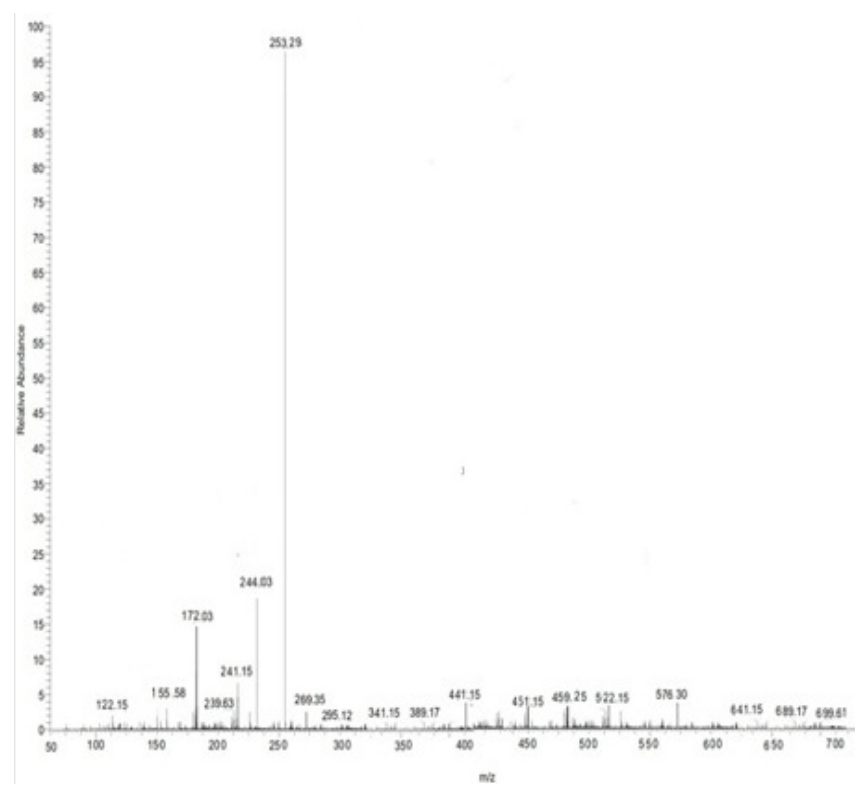

Figure 8: Mass spectra of $\mathrm{L}_{4}$. 


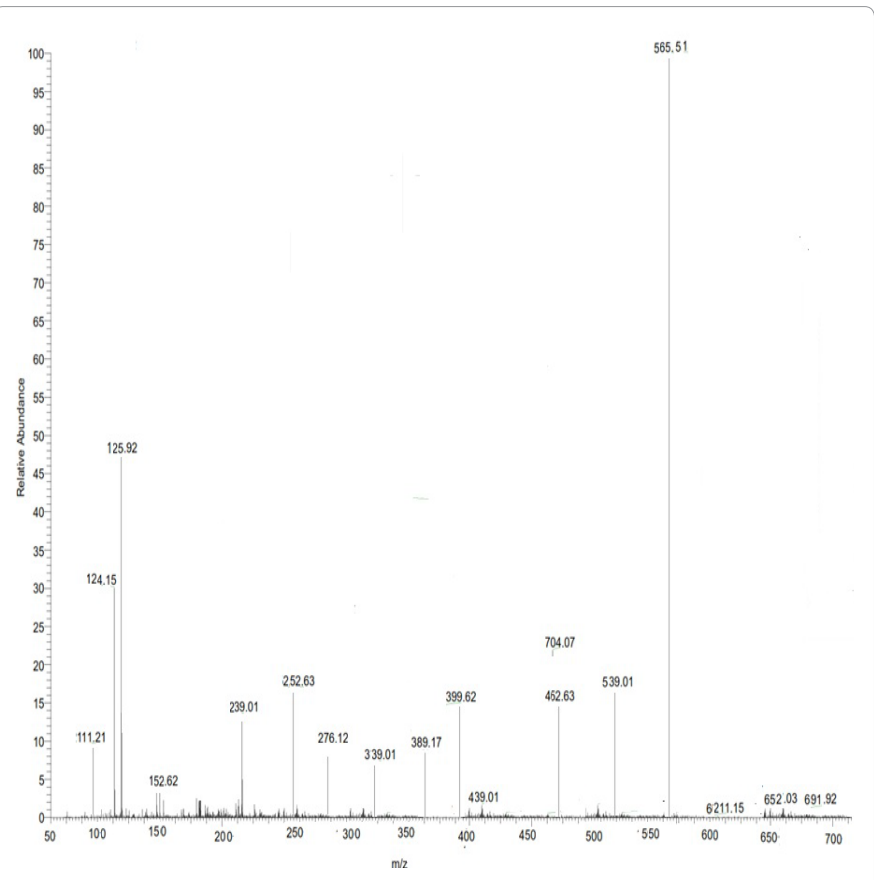

Figure 9: Mass spectra of $\left[\mathrm{Co}\left(\mathrm{L}_{4}\right)_{2}\right]$.

\begin{tabular}{|c|c|c|}
\hline S. No. & Compound & Molecular weight \\
\hline 1 & $\mathrm{~L}_{4}$ & 253.29 \\
\hline 2 & {$\left[\mathrm{Co}\left(\mathrm{L}_{4}\right)_{2}\right]$} & 565.51 \\
\hline
\end{tabular}

Table 6: Molecular weights of $L_{4}$ and its metal complexes (by Rast's method).

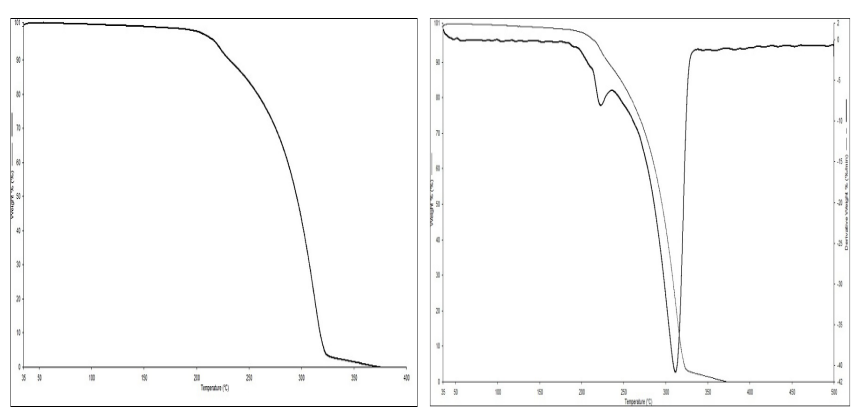

Figure 10: Thermogram of $\mathrm{L}_{4}$.

residual part of the ligand split at $300-500^{\circ} \mathrm{C}$. The straight curve indicates no change in weight $\left(0-230^{\circ} \mathrm{C}\right.$ and $\left.340-500^{\circ} \mathrm{C}\right)$ and the perpendicular potion indicate that there is weight change $\left(230-340^{\circ} \mathrm{C}\right)$. The total weight loss up to $230^{\circ} \mathrm{C}$ corresponds to two moles of ligand representing 1: 2compositions of the complex.

\section{Magnetic moment}

The magnetic moment of the complexes was determined using Guoy balance. Magnetic moment values for Cobalt complexes were found to be around 4.10 BM.

Proposed structure of metal complexes: From the above characterization details, the following structures are proposed for the complexes (Figure 12).

\section{Anti-bacterial activity}

The antibacterial activities of ligand and its metal complexes were screened against bacteria Vibrio harveyi (Plate 1), Vibrio vulnificus (Plate 2), Escherichia coli (Plate 3), Bacillus pumilus (Plate 4), by disc plate method (Plate 1).

Antibacterial activity tested against Vibrio harvey exhibiting different size zones for ligand and its metal complexes. 2,3,4-trimethoxy benzaldehyde semicarbazone $\left(\mathrm{L}_{4}\right)$ Zone number 6 , $\left[\mathrm{Co}\left(\mathrm{L}_{4}\right)_{2}\right]$ Zone number 9 (Plate 2).

Antibacterial activity tested against Vibrio vulnificus. 2,3,4-trimethoxy benzaldehyde semicarbazone $\left(\mathrm{L}_{4}\right)$ Zone no: 1 , $\left[\mathrm{Co}\left(\mathrm{L}_{4}\right)_{2}\right]$ Zone number 3 (Plate 3).

Antibacterial activity against Escherichia coli. Antibacterial activity tested against Escherichia coli. 2,3,4, -trimethoxy benzaldehyde semicarbazone $\left(\mathrm{L}_{4}\right)$ Zone no: 1, $\left[\mathrm{Co}\left(\mathrm{L}_{4}\right)_{2}\right]$ Zone number 2 (Plate 4).

Antibacterial activity tested against Bacillus pumilus., 2,3,4-trimethoxy benzaldehyde semicarbazone $\left(\mathrm{L}_{4}\right)$ Zone no: 2, $\left[\mathrm{Co}\left(\mathrm{L}_{4}\right)_{2}\right]$ Zone no 5 . The measured activity values of $\mathrm{L}_{4}$ and its metal complexes are given in the Table 7 and a graphical representation of the same is presented in Figures 12 and 13.

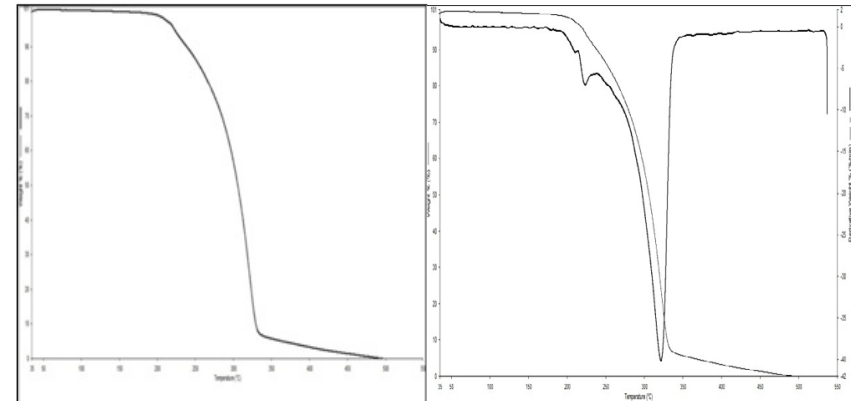

Figure 11: Thermogram of $\left[\mathrm{Co}\left(\mathrm{L}_{4}\right)_{2}\right] \mathrm{Cl}_{2}$.
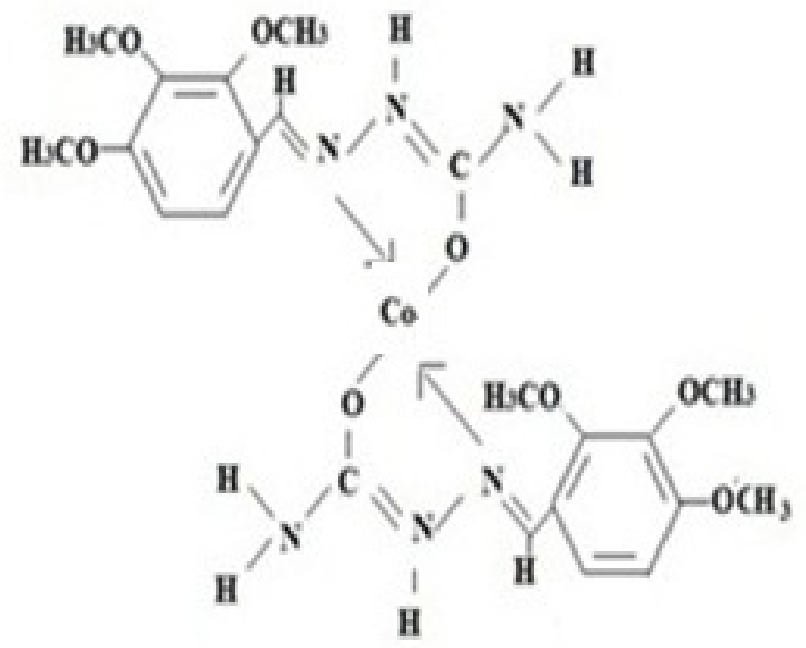

$\mathrm{M}=\mathrm{C}_{0}($ III $)$

Figure 12: Proposed structure of $M\left(L_{4}\right)_{2}$. 


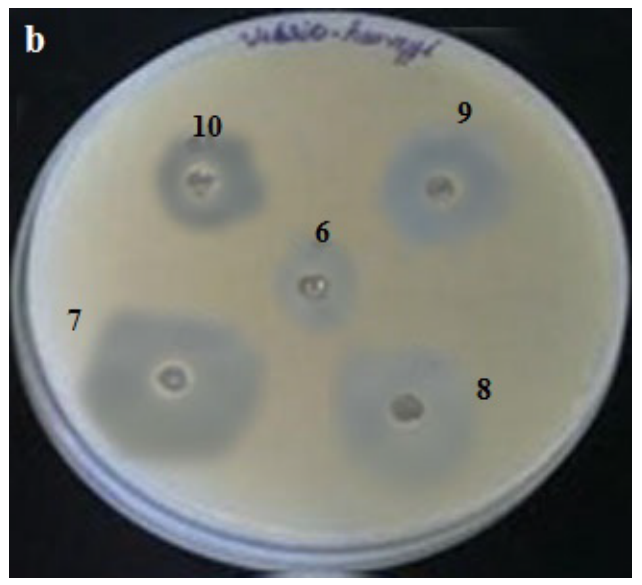

Plate 1: Antibacterial activity against Vibrio harvey.

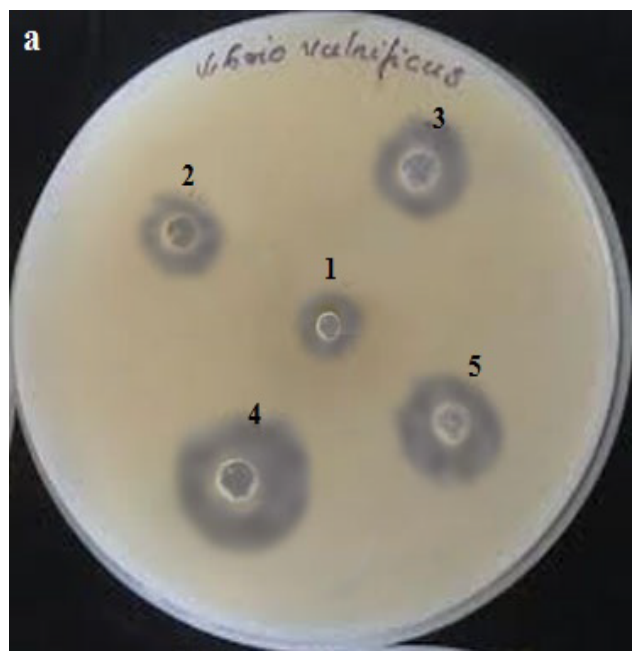

Plate 2: Antibacterial activity against Vibrio vulnificus.

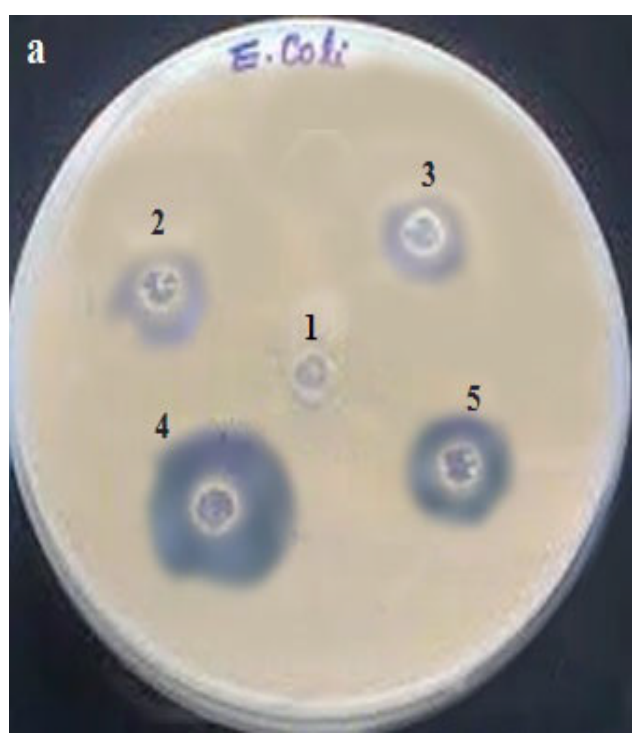

Plate 3: Antibacterial activity against Escherichia coli.

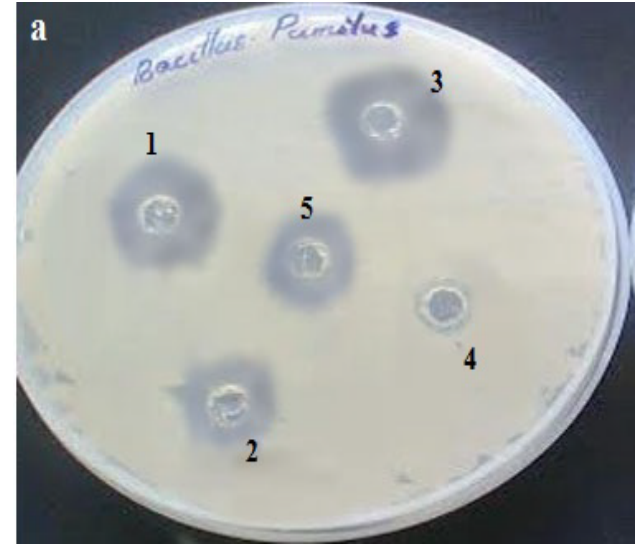

Plate 4: Antibacterial activity against Bacillus pumilus.

\begin{tabular}{|c|c|c|c|c|}
\hline Compounds & \multicolumn{3}{|c|}{ Gram-negative } & Gram-positive \\
\hline & Vibrio harveyi & Vibrio vulnificus & Escherichia coli & $\begin{array}{c}\text { Bacillus } \\
\text { pumilus }\end{array}$ \\
\hline $\mathrm{L}_{4}$ & $9 \mathrm{~mm}$ & $9 \mathrm{~mm}$ & $\mathrm{Nil}$ & $13 \mathrm{~mm}$ \\
\hline$\left[\mathrm{Co}\left(\mathrm{L}_{4}\right)_{2}\right]$ & $12 \mathrm{~mm}$ & $12 \mathrm{~mm}$ & $8 \mathrm{~mm}$ & $15 \mathrm{~mm}$ \\
\hline
\end{tabular}

Table 7: Anti-bacterial activity of $\mathrm{L}_{4}$ and its metal complexes.

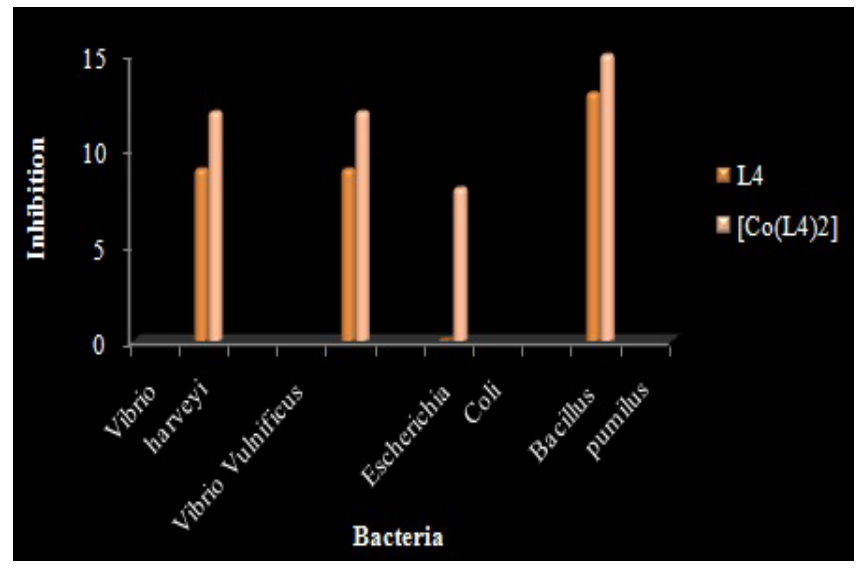

Figure 13: Anti-bacterial activity graph of $L_{4}$ and its metal complexes.

\section{Anti-fungal activity}

The antifungal activity of ligands and their metal complexes were tested against Aspergillus flavus (Plate 5) and Aspergillus niger (Plate 6). Antifungal activity tested against Aspergillus flavus. 2,3,4-trimethoxy benzaldehyde semicarbazone $\left(\mathrm{L}_{4}\right)$ Zone no: $1,\left[\mathrm{Co}\left(\mathrm{L}_{4}\right)_{2}\right]$ Zone number 3 .

Antifungal activity tested against Aspergillus niger,2,3,4-trimethoxy benzaldehyde semicarbazone $\left(\mathrm{L}_{4}\right)$ Zone No: $1,\left[\mathrm{Co}\left(\mathrm{L}_{4}\right)_{2}\right]$ Zone number 2 (Table 8 and Figure 14).

\section{Anti-oxidant activity}

The antioxidant assay study was carried out using different concentrations of the Schiff base and Co(II), metal complexes.

\section{Catalase assay}

The antioxidant activity using catalase assay were tested using ligand $\mathrm{L}_{4}$ and its metal complexes. They were found to have different 


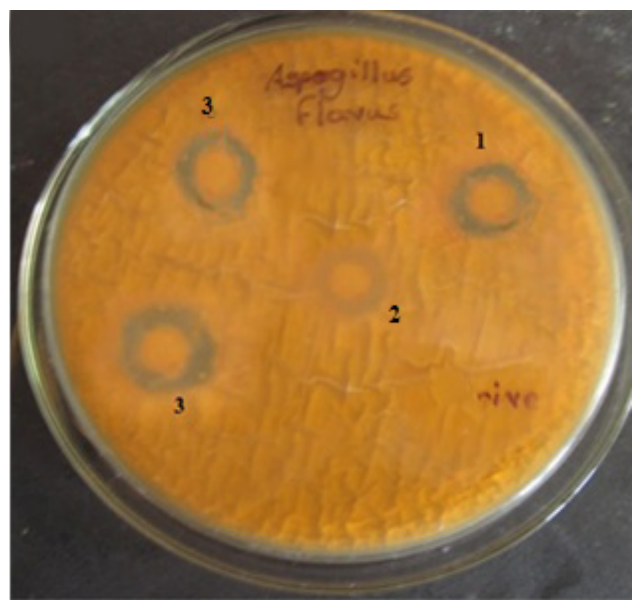

Plate 5: Antifungal activity against Aspergillus flavus.

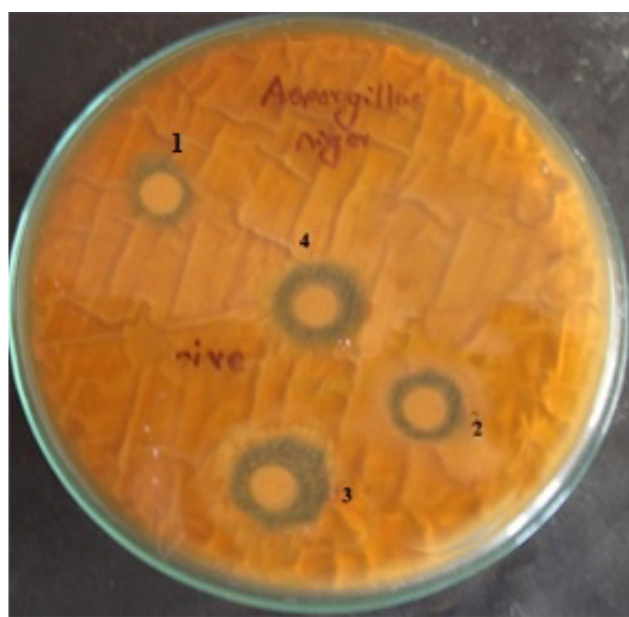

Plate 6: Antifungal activity against Aspergillus niger.

\begin{tabular}{|c|c|c|}
\hline Compounds & Aspergillus flavus & Aspergillus niger \\
\hline $\mathrm{L}_{4}$ & $11 \mathrm{~mm}$ & $8 \mathrm{~mm}$ \\
\hline$\left[\mathrm{Co}\left(\mathrm{L}_{4}\right)_{2}\right]$ & $12 \mathrm{~mm}$ & $12 \mathrm{~mm}$ \\
\hline
\end{tabular}

Table 8: Anti-fungal activity of $L_{4}$ and its metal complexes.

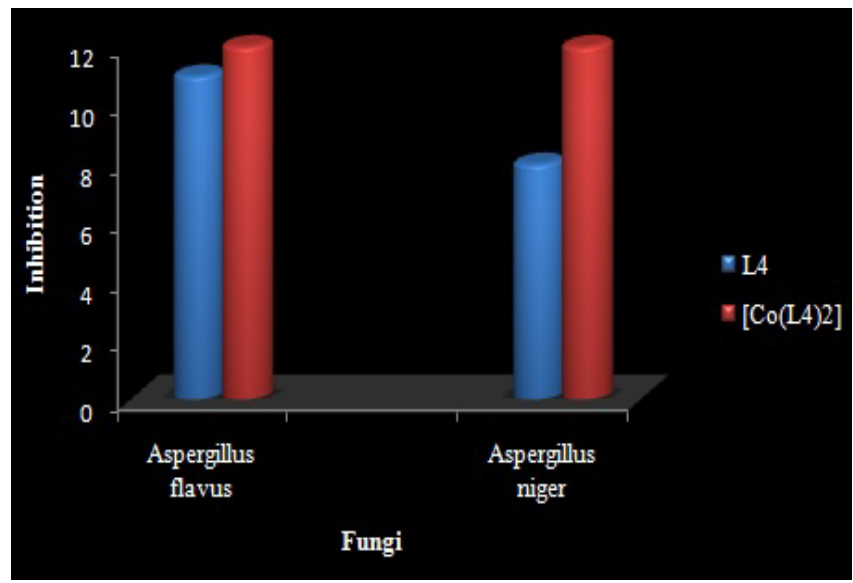

Figure 14: Anti-fungal activity graph of $\mathrm{L}_{4}$ and its metal complexes.
OD values at different time intervals (30 sec, $60 \mathrm{secs}$ and $90 \mathrm{sec}$ ). The antioxidant activities of Schiff base $\left(\mathrm{L}_{4}\right)$ and their $\mathrm{Co}(\mathrm{II})$ metal complexes were assessed in Tables 9 and 10 (Figure 15).

Catalase activity of Schiff base metal complexes was found significantly higher than that of free ligands $\left(\mathrm{L}_{4}\right)$, indicating that this complex is a much better catalase and antioxidant than the ligands. Antioxidant ability of Schiff base increased significantly after chelation of transition metal ions. The Co(II) complexes possess higher antioxidant potential than ligand.

\section{Peroxides assay}

In the present work the antioxidant activity using peroxides assay were also tested using the ligands $\left(\mathrm{L}_{4}\right)$, and their metal complexes. They were found to have different OD values at different time intervals ( 30 sec, 60 secs, 90 secs, and $120 \mathrm{sec}$ ). The activity of Schiff bases and the metal complexes were presented in Table 10 (Figure 16).

\section{Results and Discussion}

In the present work, semicarbazone [8] derivatives of isomeric trimethoxy benzaldehydes were synthesized. complexes of them with metal Co(II) [9] were also synthesized. Characterization was done by the aid of IR, UV, Magnetic moment studies, Mass, and NMR studies. Structures of the complexes were proposed using available resources. Cobalt complexes were assigned tetrahedral geometries $[10,11]$. The thermal stability of the complexes was checked using thermo-gravimetric technique. The ligands and their metal complexes were analyzed for their biological activity against various bacteria and fungi. The Co(II) complex was found to exhibit good antibacterial and antifungal activity than 2,3,4-trimethoxybenzaldehyde semicarbazone.

\begin{tabular}{|c|c|c|c|c|c|c|c|}
\hline \multicolumn{8}{|c|}{ Catalase Assay } \\
\hline \multirow[t]{2}{*}{ Sample } & \multicolumn{4}{|c|}{ OD Value } & \multicolumn{3}{|c|}{ Result \% of Inhibition } \\
\hline & $30 \mathrm{sec}$ & $60 \mathrm{sec}$ & $90 \mathrm{sec}$ & Control & $30 \mathrm{sec}$ & $60 \mathrm{sec}$ & $90 \mathrm{sec}$ \\
\hline $\mathrm{L}_{4}$ & 0.517 & 0.601 & 0.598 & 0.775 & 19 & 12.1 & 13 \\
\hline$\left[\mathrm{Co}\left(\mathrm{L}_{4}\right)_{2}\right]$ & 0.668 & 0.704 & 0.731 & 1.114 & 34 & 27.07 & 24.6 \\
\hline
\end{tabular}

Table 9: Anti-oxidant activity of $\mathrm{L}_{4}$ and its metal complexes.

\begin{tabular}{|c|c|c|c|c|c|}
\hline \multicolumn{5}{|c|}{ Peroxidase Assay } & Result Units/ml \\
\hline Sample & \multicolumn{5}{|c|}{ OD Value } \\
\hline & $30 \mathrm{sec}$ & $60 \mathrm{sec}$ & $90 \mathrm{sec}$ & $120 \mathrm{sec}$ & \\
\hline $\mathrm{L}_{4}$ & 0.741 & 0.731 & 0.724 & 0.672 & 0.001423 \\
\hline$\left[\mathrm{Co}\left(\mathrm{L}_{4}\right)_{2}\right]$ & 0.864 & 0.882 & 1.018 & 1.021 & 0.002871 \\
\hline
\end{tabular}

Table 10: Anti-oxidant activity of $\mathrm{L}_{4}$ and its metal complexes.

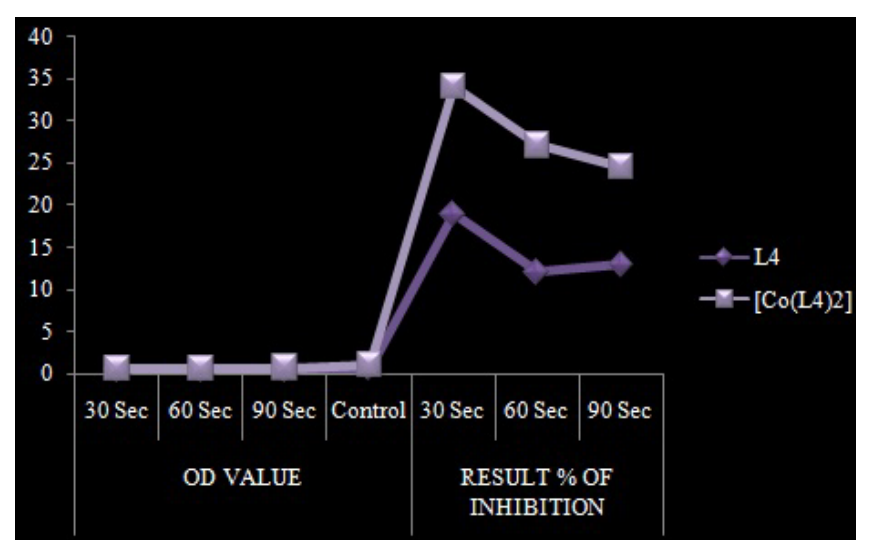

Figure 15: Anti-oxidant activity graph of $\mathrm{L}_{4}$ and its metal complexes. 
Citation: Vidhya RS, Rathika Nath G (2017) Synthesis Characterization and Biological Application of 2,3,4-Trimethoxy Benzaldehyde Semicarbazone Co(II) Metal lons. Chem Sci J 8: 176. doi: 10.4172/2150-3494.1000176

Page 7 of 7

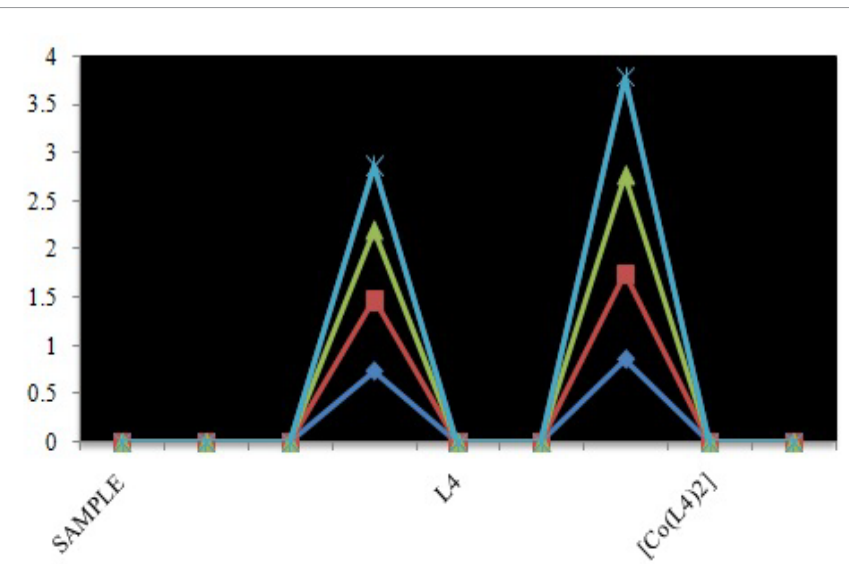

Figure 16: Anti-oxidant activity graph of $\mathrm{L}_{4}$ and its metal complexes.

Thus, is a good candidate for use in further clinical trials. The compounds were also checked for antioxidant activity and $\mathrm{Co}(\mathrm{II})$ metal complexes were found to have better activity compared to ligand. The subtle changes in biological activities may be due to the fact that in most biological activity mechanism, a lock and key mode is seen.

\section{Conclusions}

The mode of anti-bacterial and anti-fungicidal action may involve the formation of hydrogen bond through the azomethine nitrogen atom with the active Centre's of the cell constituents, resulting in the interference with the normal cell process.

\section{References}

1. Kostova I, Luciano S (2013) Advances in Research of Schiff-Base Metal Complexes as Potent Antioxidants. Current Medicinal Chemistry 20: 46094632.

2. Zemede YB, Kumar AS (2015) International Journal of Chem Tech Research 7: 279-286.

3. Reza NJM, Javed M, Gorban DM, Shahrzad J, Hamzeali H (2012) Efficient Synthesis and Deprotection of Semicarbazones under Solvent-Free Conditions, Iran. J Chem Chem Eng 31:1-8.

4. Basuli F, Peng SM, Bhattacharya S (2001) Chemical Control on the Coordination Mode of Benzaldehyde Semicarbazone Ligands, Synthesis Structure and Redox Properties of Ruthenium Complexes. Inorg Chem 40: 1126-1133.

5. Demirelli M, Tumer A, Bull G (2006) Chem Soc Jpn 79: 867.

6. Dolaz M, Tumer M (2004) Synthesis, Spectroscopic Characterization and Properties of New Metal Complexes. Trans Metal Chem 29: 516-522.

7. Casas JS, Garcia-Tasende MS, Sordo J (2000) Main group metal complexes of semicarbazones and thiosemicarbazones - A structural review. Coord Chem Rev 209: 197.

8. Mohamed GG, Omar MM, Hindy AM (2006) Metal Complexes of Schiff Bases: Preparation, Characterization, and Biological Activity. Turk J Chem 30: 361-382.

9. Kadhim ZN (2015) Synthesis and Electrochemical Study of Cu (II) Complex with Neutral [N2O2] Donor Schiff Base. J Mater Enviro Sci 6: 693-698.

10. Kilic A, Tas E, Deverci B, Yilmaz I (2007) Synthesis, electrochemical and in situ spectroelectrochemical studies of new transition metal complexes with two new Schiff-bases containing N2O2/N2O4 donor. Polyhedron 26: 4009.

11. Prakash A, Adhikari D (2011) Application of Schiff bases and their metal complexes - A Review. Int J Chem Tech Res 3: 1891-1896. 